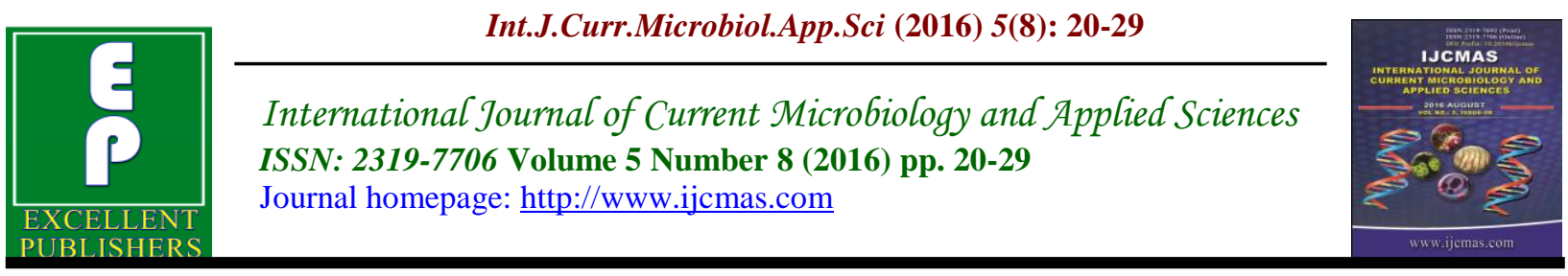

Original Research Article

http://dx.doi.org/10.20546/ijcmas.2016.508.003

\title{
Evaluation of Antimicrobial and Antioxidative Activities of the Aerial Plant Extracts of Elytraria acaulis
}

\author{
B. Suresh Babu*, M. Lakshmi Narasu, B. Venkanna, Kodaparthi Ashwitha, \\ CH. Kalyani and CH. Narmada
}

Centre for Biotechnology, Institute of Science and Technology, Jawaharlal Nehru Technological University Hyderabad, Kukatpally, Hyderabad-500 085, Telangana State, India

*Corresponding author

\begin{abstract}
A B S T R A C T
Keywords

Aerial parts,

Antimicrobial

activities,

Antioxidant assays,

Elytraria acaulis,

Organic solvents,

Pathogenic bacterial

infections.

Article Info

Accepted:

06 July 2016

Available Online:

10 August 2016

Antimicrobial and Antioxidative activities of the aerial parts of the Elytraria acaulis a stem less perennial herb of Acantheceae family has been carried out in the present study. Extracts of the aerial parts of the plant (Stem \& Leaves) were prepared in different organic solvents such as n-Hexane, ethanol, methanol and ethyl acetate. Initially total phenolic \& total flavonoid content of the aerial parts in different solvent extracts was estimated. All the extracts were analyzed for antimicrobial properties against various pathogenic bacterial infections (Escherichia coli, Klebsiella Species, Proteus vulgaris and Salmonella Typhi). Amongst all the extracts, methanolic extract exhibited significant antimicrobial activity. The crude methanol extracts of leaves showed good inhibitory effects against pathogens. The free radical scavenging and antioxidant activity (AA) of the aerial extracts of Elytraria acaulis in different organic solvents was also assayed by DPPH assay, reducing power assay and FRAP assay. The aerial extracts of Elytraria acaulis has shown significant antimicrobial and anti oxidant activity. Hence further studies on this plant will enable elucidation of its therapeutic properties and medicinal applications.
\end{abstract}

\section{Introduction}

Anti-microbial substances are biological, semi-synthetic/synthetic origin produced by fungus/ bacterium or by medicinal herbs as secondary metabolites that stops or inhibits the growth of other micro-organisms in-vitro or in-vivo selectively. However, over the past few decades, the primary health care of humans are under threat due to emergence of drug-resistant bacteria, which makes it is essential to investigate newer drugs with lesser resistance.
It has been known that drugs derived from natural sources play significant roles in the prevention and treatment of human diseases. Moreover, natural products of higher plants can be new source of antimicrobial agents with novel mechanisms of action. Therefore, the effects of plant extracts on bacteria have been studied by researchers worldwide and most of them on ethnomedicinal plants in India. 
On the other hand, antioxidants are substances that protect cells from the damage caused by free radicals. Antioxidants interact with and stabilize free radicals and prevent the damage which may lead to cancer. Examples of antioxidants include beta-carotene, glutathione, lycopene, vitamins $\mathrm{C}$, E, A well as enzymes such as catalase, superoxide dismutase and various peroxidases and other substances (Blot et al., 1993). Low levels of antioxidants, or inhibition of the antioxidant enzymes, causes oxidative stress and may damage or kill cells. As oxidative stress might be an important part of many human diseases, the use of antioxidants in pharmacology is intensively studied, particularly for treatments of stroke and neurodegenerative diseases (Xianquan et al., 2005).

Antioxidants are also widely present as ingredients in dietary supplements maintaining health and preventing diseases such as cancer and coronary heart disease. Although, initial studies suggested that antioxidant supplements might promote health, later, large clinical trials did not detect any benefit and suggested instead that excess supplementation may be harmful (Steinmetz et al., 1996).

Free-radicals are very unstable and react quickly with other compound by abstracting its electron to attain stability. When the attacked molecule loses its electron, it becomes a free-radical itself, resulting in the disruption of the substance especially in fatty foods. Environmental factors such as pollution, radiation, cigarette smoking and herbicides can also spawn free-radicals in the body (Borek, 1991).

Elytraria acaulis is a stem less perennial herb belonging to acantheceae family of plant kingdom which is a small shrub that grows in shady dry places. Asian Scalystem is a stemless perennial herb with one to several unbranched flowering stems; up to $30 \mathrm{~cm}$. Flowers are obrne in spikes held in tight, overlapping bracts. This plant is often found on often on rocky or sandy soils. It is a traditional herb, is the whole plant is used for medicinal purposes. Therapeutic efficacy of many indigenous plants for several disorders has been described by practitioners of traditional medicine. The World Health Organization estimates that plant extracts or their active constituents are used as folk medicine in traditional therapies of $80 \%$ of the world's population. The pharmacological industries have produced a number of new antibiotics; however, resistance to these drugs by microorganisms has increased due to their genetic ability to transmit and acquire resistance to synthetic drugs.

The microorganisms which are used to check the anti-microbial activity are Escherichia coli, Salmonella typhi, proteus vulgaris, and klebsiella. All these microbes are effective pathogens and cause numerous diseases in human beings. As mentioned earlier, due to prolong use of synthetic antibiotics, these microbes have gained resistance because of which infection/diseases caused by these have become difficult to cure.

\section{Materials and Methods}

\section{General}

Chemicals: Nutrient Broth, Nutrient Agar, chloroform, methanol, ethyl acetate, nhexane, etc., were obtained from Hi Media, Mumbai, India. The standard reference antibiotic, Streptomycin.

Microorganisms: The different strains of MRSA infected patients like that etc., Klebsiella, Proteus vulgaris, salmonella typhii, and Escherichia coli (ATCC 8739) at Global Hospital, Hyderabad. All the four 
cultures were maintained in Muller Hinton broth as well as on agar slants at $4^{\circ} \mathrm{C}$.

\section{Preparation of solvent extracts from different parts of plant material}

Fresh leaves and stem of Elytraria acaulis were procured from local gardens at Hyderabad, India. The collected material was washed thoroughly with distilled water and freeze dried. The dried samples were ground to powder and stored in tight container at $-20^{\circ} \mathrm{C}$ until further use. Then the processed plant materials were subjected to fractionation using n-hexane, ethyl acetate, methanol and water in the order of increasing in polarity. The extraction procedure was carried out at room temperature for $72 \mathrm{~h}$ using mass to volume ratio of 1:10. Plant samples were then subjected to sequential extraction using hexane $(\mathrm{H})$, followed by Ethyl acetate (EA), Methanol (M), and finally with Ethanol (E). By using a Rotary Evaporator each solvent present in the extracted material was evaporated at its respective boiling point. The solvent free extracts were dissolved in DMSO and were screened for their activity against the selected multi drug resistant pathogens.

\section{Standardized bacterial colony numbers}

In order to ensure that the same number of bacteria was always used, a set of bacterial growth curves was established in the laboratory using the method described by Cappuccino \& Sherman (2005) for each bacterial strain prior to the evaluation of antimicrobial activities. From these curves, we determined the optical density (OD) at $600 \mathrm{~nm}$ that corresponded to the desired number of colony forming units (CFU).

\section{Preparation of test samples}

One hundred milligrams (100mg) of plant extracts was dissolved in $1 \mathrm{ml}$ dimethyl sulfoxide (DMSO) while $1 \mathrm{mg}$ of streptomycin was dissolved in $1 \mathrm{ml}$ sterile deionised water. Ten microliters of $100 \mathrm{mg} / \mathrm{ml}$ plant extract (equivalent to $1 \mathrm{mg}$ dose), $10 \mu \mathrm{l}$ of $1 \mathrm{mg} / \mathrm{ml}$ streptomycin (each equivalent to $10 \mu \mathrm{g}$ dose).

\section{Total Phenolic Content Assay (Ali Ghasemzadeh et al., 2010)}

Chemicals: Galic acid (Standard solution$1 \mathrm{mg} / \mathrm{ml}$ ), Folin's reagent, Deionized water, and $20 \% \mathrm{NaCO} 3$.

Procedure: 1. Using Folin-Ciocalteu reagent with analytical grade gallic acid as standard $1 \mathrm{ml}$ of extract or standard solutions $(1 \mathrm{mg} / \mathrm{ml}$ of range $100-1000$ $\mathrm{mg} / \mathrm{ml}$ ) was added to $10 \mathrm{ml}$ of deionized water to each sample. 2. To this add $0.1 \mathrm{ml}$ of F-C reagent to each sample. 3. After 5 minutes of incubation, $20 \%$ of sodium carbonate $(2.0 \mathrm{ml})$ was added to the each mixture. 4. After being kept in total darkness for $1 \mathrm{hr}$, the absorbance was measured at 750nm using a spectrophotometer. 5. Amounts of total phenolic content were calculated using gallic acid calibration curve.

Total FlavinoidC ontent (Mccall et al., 1999; Chen et al., 2002)

Chemicals: Quercetin (Standard solution), $5 \% \mathrm{NaNO} 2,10 \% \mathrm{AlCl} 3,1 \mathrm{M} \mathrm{NaOH}$, and Distilled water.

Procedure: 1. Prepare standard solutions of concentration $1 \mathrm{mg} / \mathrm{ml}$ (ranging from $100 \mathrm{mg} / \mathrm{ml}-1000 \mathrm{mg} / \mathrm{ml}$ ) and make up the volume to $5 \mathrm{ml}$ using distilled water accordingly. 2. Add $0.3 \mathrm{ml}$ of $5 \% \mathrm{NaNO} 2$ and leave it for $5 \mathrm{~min}$. Then add $0.3 \mathrm{ml}$ of $10 \% \mathrm{AlCl} 3$. After $5 \mathrm{~min}$ add $2 \mathrm{ml}$ of $1 \mathrm{M}$ $\mathrm{NaOH}$ and make up the volume to $10 \mathrm{ml}$ with distilled water accordingly. 3 . Read the absorbance at $510 \mathrm{~nm}$ using UV- 
Spectrophotometer. 4. Plot a standard graph taking concentrations of the standard on $\mathrm{x}$ axis against O.D on y-axis.

\section{Antimicrobial Testing Methods}

Well-in agar (wa): Well-in agar assay was carried out according to the method with some modifications. Bacteria colonies from plates were grown in NB until they reached their specific OD at $600 \mathrm{~nm}$ to give starting inoculums of $1 \times 10^{8}$ bacteria $/ \mathrm{ml}$. Nutrient agar plates were each divided into quadrants and labeled accordingly. One hundred micro liters of inoculums, equivalent to $10^{7} \mathrm{CFU}$, was mixed with $6 \mathrm{ml}$ of molten soft NA (to ensure even distribution of bacteria) and poured immediately onto the base layer of NA. The plates were left to solidify for $10 \mathrm{~min}$. A sterilized $5 \mathrm{~mm}$ borer was used to make holes in the centre of the divided areas. The bottom of the well was then sealed with molten soft agar. Ten micro liters of each of the test samples [plant extracts, streptomycin or penicillin (these were used as positive controls) \& DMSO (used as negative control)] was then pipette into the holes.

Bacterial growth condition: Acquisition Plates with bacteria and test samples were incubated at $37{ }^{\circ} \mathrm{C}$ for 16 to $18 \mathrm{~h}$ after which the inhibition diameter (ID) was measured using a caliper. Each experiment was carried out on at least three separate occasions.

MIC and MBC: The minimum inhibitory concentration and maximum bactericidal concentration were determined by the broth dilution method with modification done. $4 \mathrm{ml}$ nutrient broth was dispensed in 6 test tubes. Into the first tube add $1 \mathrm{ml}$ of plant extract and then serially dilute. The stock concentration of plant extract was $5 \mathrm{mg} / \mathrm{ml}$ and it was diluted up to $0.004 \mathrm{mg} / \mathrm{ml}$. Then add $0.1 \mathrm{ml}$ of $24 \mathrm{hrs}$ old bacterial culture in all the tubes and incubate it for $24 \mathrm{hrs}$ at 370 C. After incubation MIC \& MBC were calculated by comparing it with blanks (positive control). The lowest concentration that did not show any visible growth after macroscopic evaluation was considered as MIC. After the determination of MIC, the tubes which did not show any visible growth was diluted 100 fold with drug free NB and incubated at $37^{\circ} \mathrm{C}$ for $48 \mathrm{hrs}$. The lowest concentration of the tube that did not show any visible growth was considered as the maximum bactericidal concentration (MBC). The assays were performed in triplicates.

\section{Anti-Oxidant Activity}

DPPH Assay (Patel Rajesh et al., 2011; Aruna Prakash, 2000)

Chemicals: DPPH $-0.1 \mathrm{mM}$, Ethanol, and Ascorbic acid-98\% (standard solution).

Procedure: 1. Prepare $0.1 \mathrm{mM}$ of DPPH solution dissolved in ethanol. 2. Simultaneously prepare standard solution of concentration $\quad 1 \mathrm{mg} / \mathrm{ml} \quad(100 \mathrm{mg} / \mathrm{ml}-$ $1000 \mathrm{mg} / \mathrm{ml})$. 3. Make up the volume to $1 \mathrm{ml}$ using ethanol for each standard solution. 4. Add $3 \mathrm{ml}$ of DPPH to each test tube and incubate for $15 \mathrm{~min}$. 5. Read the OD at 517 nm. 6. Calculate the antioxidant activity using the following formula:

$\%$ scavenging $=$ [Absorbance of controlAbsorbance of test sample/Absorbance of control] X 100.

Frap Assay (Selvakumar; Gohari et al., 2011; Iris et al., 1996)

Chemicals: FeSO4.7H2O (standard solution of $100-1000 \mu \mathrm{g} / \mathrm{ml}$ ), Frap Reagent - a) acetate buffer - $30 \mathrm{mM}$, Ph-3.6 [200 ml], TPTZ $-10 \mathrm{mM}$ in $\mathrm{HCl}(40 \mathrm{mM})$ [20 $\mathrm{ml}$, 
FeCl3-20mM [20ml], and distilled water [24 ml].

Procedure: 1. $200 \mathrm{Ml}$ of extracted sample was mixed with $3 \mathrm{ml}$ of FRAP reagent in a test tube. The same is repeated taking standard solution as ferrous sulphatehepta hydrated (FeSO4.7H2O). 2. Incubate at 37 degree celcius for $30 \mathrm{~min}$ in water bath. 3 . Read the absorbance at $593 \mathrm{~nm}$. 4. Plot a standard graph taking concentrations of the standard on $\mathrm{x}$-axis against OD on $\mathrm{y}$-axis.

\section{Results and Discussion}

Natural antioxidants that are present in herbs and spices are responsible for inhibiting or preventing the deleterious consequences of oxidative stress. Spices and herbs contain free radical scavengers like polyphenols, flavonoids and phenolic compounds.

Several reports have conclusively shown close relationship between total phenolic contents and antioxidative activity of the different plants. Since the chemical composition and structures of active extract components are important factors governing the efficacy of natural antioxidants, the antioxidant activity of an extract could not be explained on the basis of their phenolic content, which also needs their characterization. These results from various free radical-scavenging systems revealed that the Elytraria acualis had significant antioxidant activity and free radicalscavenging activity.

Table.1 Determination of total phenolic content for methanol, ethanol and ethyl acetate extracts of Elytraria acaulis

\begin{tabular}{|c|c|c|c|c|}
\hline $\begin{array}{c}\text { Concentration } \\
(\mathbf{1 0 0 - 1 0 0 0} \boldsymbol{\mu g} / \mathbf{m l})\end{array}$ & Methanol & Ethanol & Ethyl acetate & Gallic Acid \\
\hline 200 & 0.021 & 0.023 & 0.021 & 0.78 \\
\hline 400 & 0.031 & 0.048 & 0.027 & .113 \\
\hline 600 & 0.039 & 0.057 & 0.033 & 0.120 \\
\hline 800 & 0.046 & 0.061 & 0.041 & 0.147 \\
\hline 1000 & 0.058 & 0.075 & 0.049 & 0.198 \\
\hline
\end{tabular}

Table.2 Determination of total flavonoid content for methanol, ethanol and ethyl acetate exacts.

\begin{tabular}{|c|c|c|c|c|}
\hline $\begin{array}{c}\text { Concentration } \\
(\mathbf{1 0 0 - 1 0 0 0} \boldsymbol{\mu g} / \mathbf{m l})\end{array}$ & Methanol & Ethanol & Ethyl acetate & quericitin \\
\hline 200 & 1.539 & 0.437 & 0.306 & 0.066 \\
\hline 400 & 1.724 & 0.640 & 0.591 & 0.170 \\
\hline 600 & 1.906 & 0.725 & 0.623 & 0.193 \\
\hline 800 & 2.406 & 0.870 & 0.714 & 0.262 \\
\hline 1000 & 2.661 & 0.906 & 0.808 & 0.324 \\
\hline
\end{tabular}


Table.3 Antibacterial effect of Elytraria acaulis plant aerial extract against pathogenic bacterial strains

\begin{tabular}{|c|c|c|c|c|c|}
\hline \multirow{2}{*}{$\begin{array}{c}\text { Name of the } \\
\text { organisms }\end{array}$} & \multicolumn{4}{|c|}{ Diameter of zone inhibition $(\mathbf{m m})(\mathbf{1 0 m g} / \mathbf{m l}$ Concentration) } \\
\cline { 2 - 6 } & Ethyl acetate & Methanol & Ethanol & Hexane & Streptomycin \\
\hline Escherichia coli & $13 \pm 10$ & NI & $12 \pm 10$ & $20 \pm 7$ & 39 \\
\hline $\begin{array}{c}\text { Klebsiella } \\
\text { pneumonia }\end{array}$ & $15 \pm 9$ & $11 \pm 9$ & $13 \pm 10$ & $16 \pm 10$ & 27 \\
\hline Proteus vulgaris & $15 \pm 10$ & $15 \pm 8$ & $20 \pm 9$ & $14 \pm 11$ & 35 \\
\hline Salmonella typhi & $16 \pm 12$ & $15 \pm 10$ & $14 \pm 4$ & $14 \pm 12$ & 16 \\
\hline
\end{tabular}

Table.4 Determination of Minimum inhibitory and bactericidal concentrations of Elytraria acaulis plant aerial extract and Streptomycin effect on pathogenic bacterial strains

\begin{tabular}{|c|c|c|c|c|c|}
\hline \multicolumn{2}{|c|}{$\begin{array}{c}\text { Plant extract } \\
\text { 10mg/ml }\end{array}$} & $\begin{array}{c}\text { Escherichia } \\
\text { coli }\end{array}$ & $\begin{array}{c}\text { Klebsiella } \\
\text { pneumonia }\end{array}$ & $\begin{array}{c}\text { Proteus } \\
\text { vulgaris }\end{array}$ & $\begin{array}{c}\text { Salmonella } \\
\text { typhi }\end{array}$ \\
\hline \multirow{2}{*}{$\begin{array}{c}\text { Ethyl } \\
\text { Acetate }\end{array}$} & MIC & 0.312 & 0.312 & 0.312 & 0.312 \\
\cline { 2 - 6 } Methanol & MBC & 1.25 & 1.25 & 1.25 & 1.25 \\
\cline { 2 - 6 } & MIC & - & 0.312 & 0.312 & 0.078 \\
\cline { 2 - 6 } Ethanol & MBC & - & 1.25 & 1.25 & 0.312 \\
\cline { 2 - 6 } & MBC & 0.312 & 0.312 & 0.312 & 0.312 \\
\hline \multirow{2}{*}{ Hexane } & MIC & 0.312 & 0.312 & 0.078 & 0.312 \\
\cline { 2 - 6 } & MBC & 1.25 & 1.25 & 0.312 & 1.25 \\
\hline \multirow{2}{*}{ Streptomycin } & MIC & 0.04 & 0.008 & 0.25 & 0.004 \\
\cline { 2 - 6 } & MBC & 0.08 & 0.032 & 0.05 & 0.032 \\
\hline
\end{tabular}

Table.5 Determination of FRAP activity for methanol, ethanol and ethyl acetate extracts

\begin{tabular}{|c|c|c|c|c|}
\hline $\begin{array}{c}\text { Concentration } \\
(\mathbf{1 0 0 - 1 0 0 0} \boldsymbol{\mu g} / \mathbf{m l})\end{array}$ & Methanol & Ethanol & Ethyl acetate & FeSO $_{\mathbf{4} .7 \mathbf{H}_{2} \mathbf{O}}$ \\
\hline 200 & 1.890 & 0.989 & 0.417 & 0.076 \\
\hline 400 & 2.236 & 1.208 & 0.520 & 0.154 \\
\hline 600 & 2.792 & 1.509 & 0.696 & 0.250 \\
\hline 800 & 3.106 & 2.364 & 0.730 & 0.280 \\
\hline 1000 & 3.341 & 2.967 & 0.837 & 0.352 \\
\hline
\end{tabular}

Table.6 Standard table of DPPH scavenging assay for ascorbic acid

\begin{tabular}{|c|c|c|c|c|c|}
\hline $\begin{array}{c}\text { Concentration } \\
\mathbf{( 1 0 0 - 1 0 0 0} \boldsymbol{\mu g} / \mathbf{m l})\end{array}$ & Methanol & Ethanol & Ethyl acetate & Ascorbic acid & $\begin{array}{c}\text { Inhibition } \\
(\boldsymbol{\%})\end{array}$ \\
\hline 200 & 8.41 & 17.75 & 17.75 & 0.192 & 10.28 \\
\hline 400 & 28.50 & 57.47 & 38.31 & 0.173 & 19.15 \\
\hline 600 & 57.00 & 64.48 & 50.93 & 0.159 & 25.17 \\
\hline 800 & 86.44 & 75.23 & 55.00 & 0.132 & 38.31 \\
\hline 1000 & 95.00 & 81.77 & 78.50 & 0.116 & 45.79 \\
\hline
\end{tabular}


Fig.1 Total phenolic content for methanol, ethanol and ethyl acetate extracts of Elytraria acaulis

Determination of total phenolic content for methanol, ethanol and ethyl acetate extracts of Elytraria acaulis

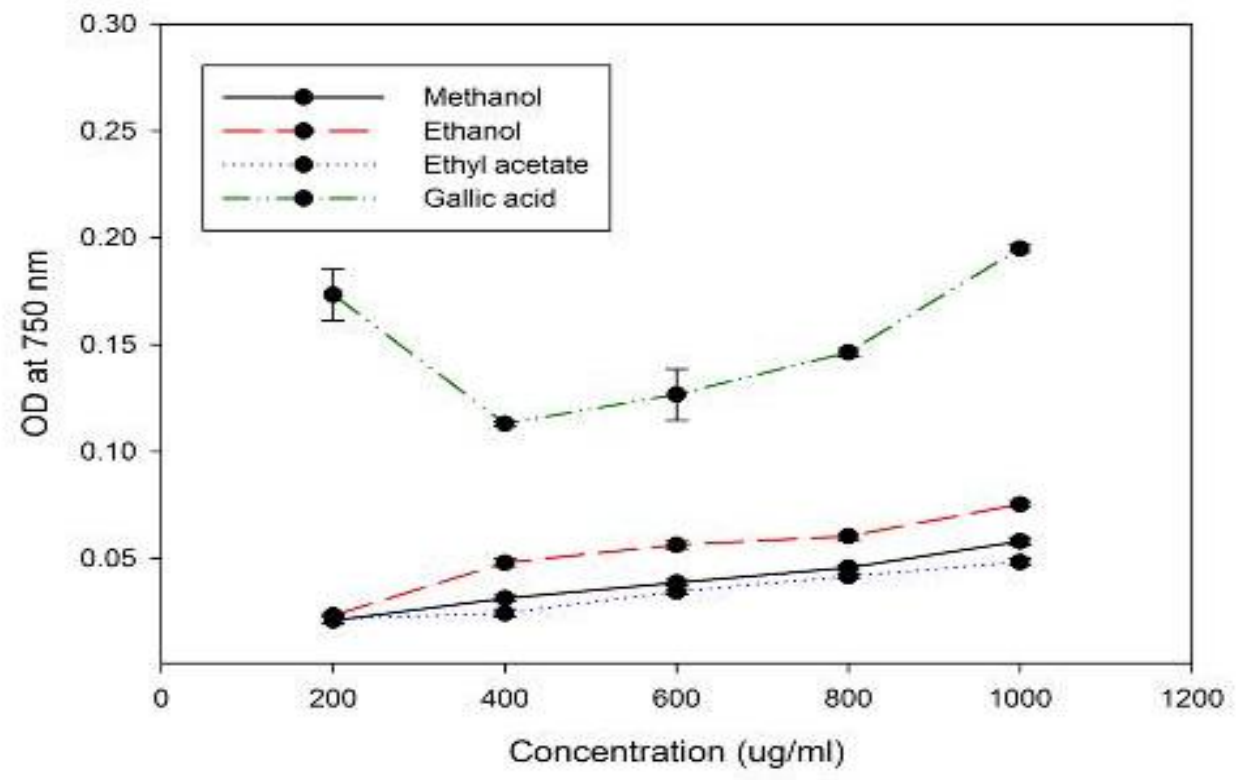

Fig.2 Total flavonoid content for methanol, ethanol and ethyl acetate exacts.

Determination of total flavonoid content for methanol, ethanol and ethyl acetate exacts

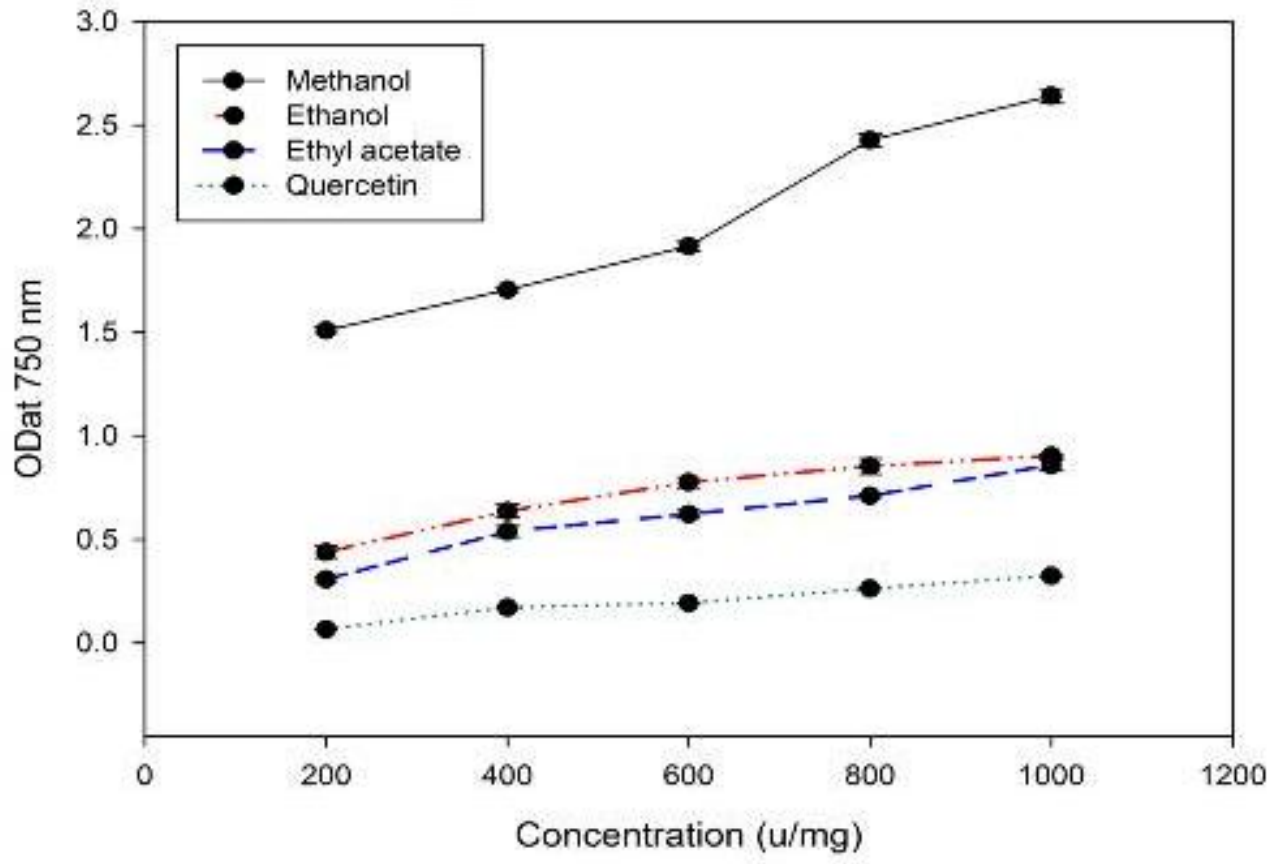


Fig.3 Antibacterial effect of Elytraria acaulis extract with different solvents in comparison with streptomycin (a positive control antibiotic).

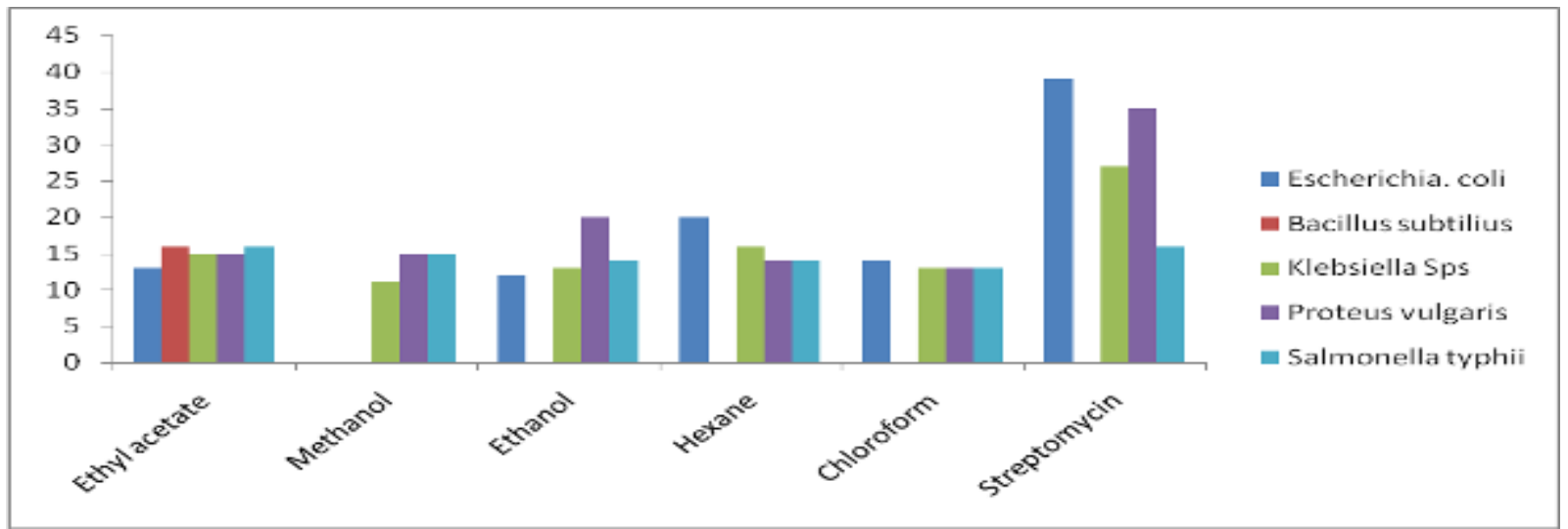

Fig.4. Antibacterial effect of different solvents and Elytraria acaulis extract of arial parts in comparison with streptomycin (a positive control antibiotic)

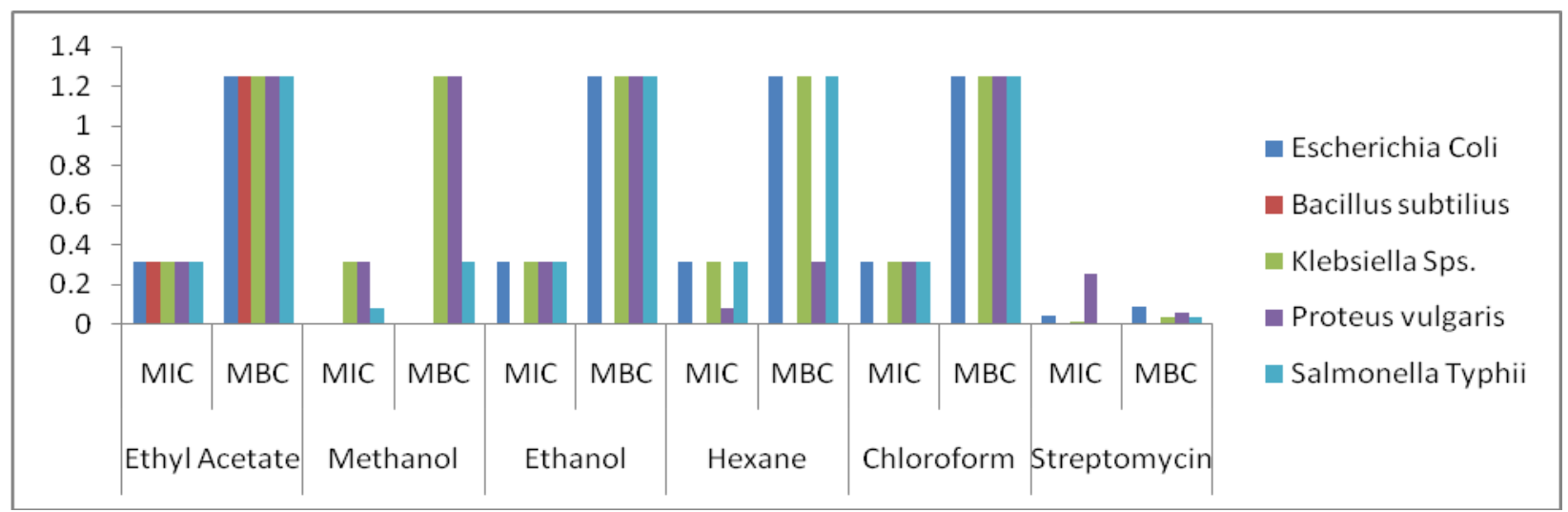

Fig.5 FRAP activity for methanol, ethanol and ethyl acetate extracts

\section{Determination of FRAP activity for methanol, ethanol and ethyl acetate extracts}

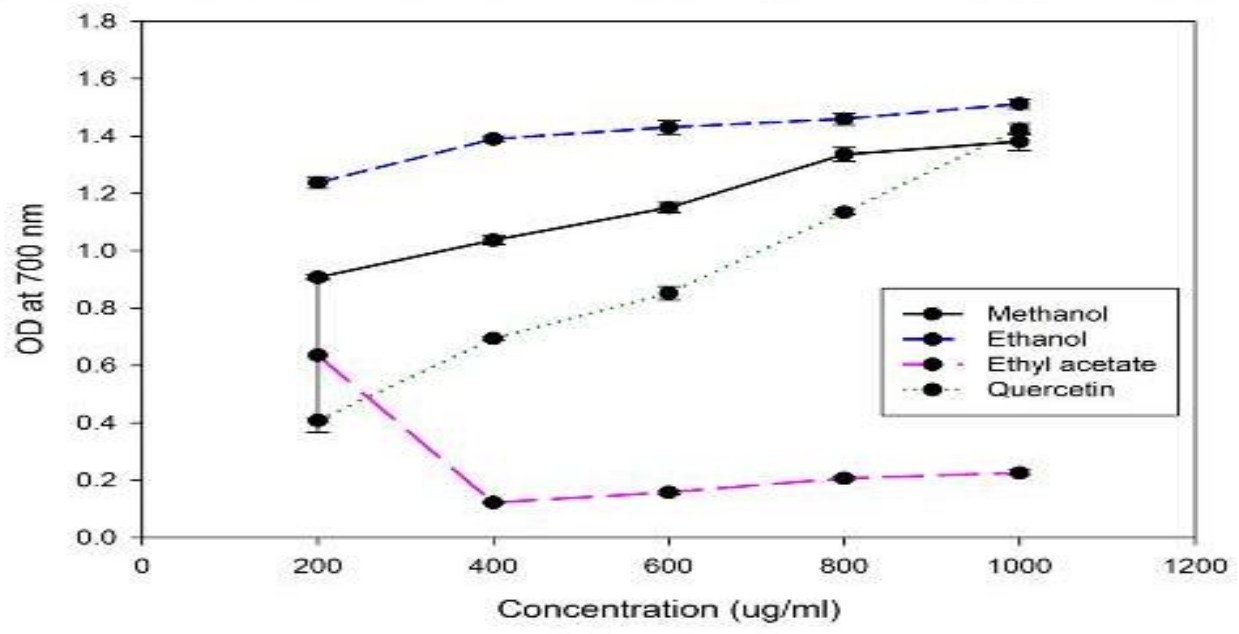


Fig.6 DPPH scavenging assay for ascorbic acid

DPPH scavenging assay for ascorbic acid

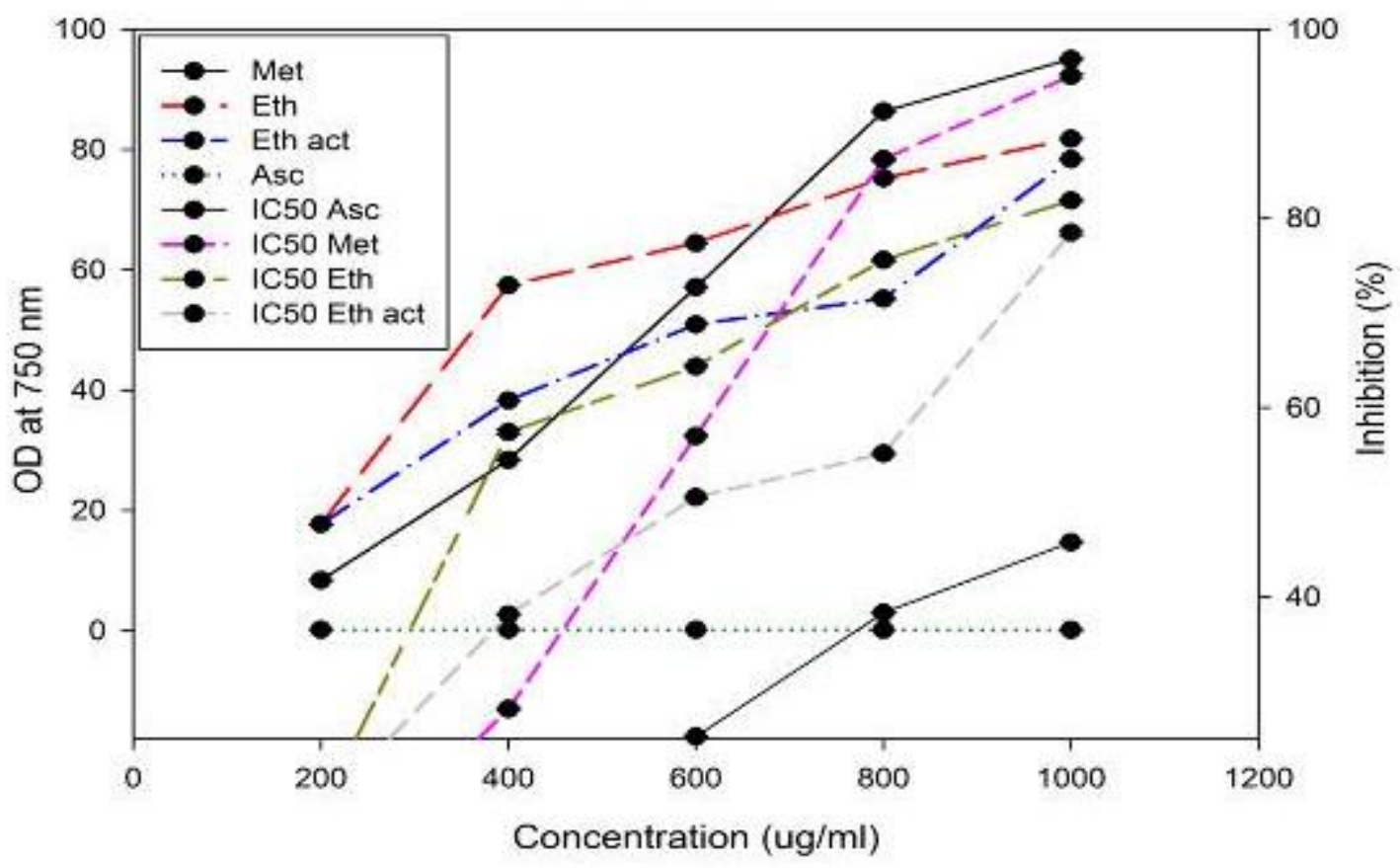

In this case, for FRAP assay the maximum absorbance was shown at $200 \mu \mathrm{g} / \mathrm{ml}$ itself i.e., $1.890,0.989$ and $0.417 \mathrm{OD}$ at $593 \mathrm{~nm}$ for methanol, ethanol and ethyl acetate extracts respectively when compared to that of the ferrous sulphate hepta hydrate taken as a standard of concentration $1000 \mu \mathrm{g} / \mathrm{ml}$ showing 0.352 OD units.

Among the five extracts and standard tested for the in vitro antioxidant activity using the DPPH method and the crude methanolic, ethanolic and ethyl acetate extracts of Elytraria acualis showed antioxidant activity, with maximum of $57 \%$ (at 600 $\mu \mathrm{g} / \mathrm{ml}) ; 57.47 \%(400 \mu \mathrm{g} / \mathrm{ml})$ and $50.93 \%$ $(600 \mu \mathrm{g} / \mathrm{ml})$ respectively when compared to that of the standard (ascorbic acid) that gave $45.79 \%$ (at $1000 \mu \mathrm{g} / \mathrm{ml}$ ) activity. The results indicate that the antioxidant activity of the crude extract of Elytraria acualis is higher than that of ascorbic acid. The results and observations are presented in tables 1,2,3, 4,5 , and 6 and figs.1, 2, 3, 4, 5 and 6.
In conclusion, in view of the continuous rise of antibiotic resistant bacterial strains, the present study was undertaken to analyze antibacterial activity and Anti oxidants of the aerial extracts of Elytraria acaulis and the findings clearly indicate that Elytraria acaulis has profound antimicrobial activity against the pathogenic strains. These results are supportive to the traditional use of Elytraria acaulis against multidrug resistant parasites of pathogenic strains. Many substances consumed by man either through foods, drinks and inhalation, even effect of exogenous material (ultraviolet radiation) on the skin may be destructive to the health and thus, shortening the life span of man. Free radicals when generated in the body system of man causes damage to which eventually leads to death at shorter time. Continuous usage of the same vegetable oil which is not even properly stored and re-using the already fried oil (rancid) lead to generation of free radicals through lipid peroxidation. Further research is being carried out in our 
laboratory for the determination of mechanism of action, toxicological studies and formulation of the compound.

\section{References}

Ali Ghasemzadeh, Hawa, Z.E., Jaafar, Asmah Rahmat. 2010. Mol., 15: 43244333.

Aruna Prakash. 2000. Fred Rigelhof and Eugene MIller, and Miller, H.E., Rigelhof, F., Marquart, L., Prakash, A., and Kanter, M. Cereal Foods World, 45(2): 59-63.

Blot, W.J., Li, J.Y., Taylor, P.R., Chu, Y.H., and Hsu, H.F. 1993. Nutrition intervention trials in Linxian, China: supplementation with specific vitamin/mineral combinations, cancer incidence, and disease-specific mortality in the general population. The Alpha-Tocopherol, Beta Carotene Cancer Prevention Study Group. The effects of vitamin $\mathrm{E}$ and beta carotene on the incidence of lung cancer AND.

Borek, C. 1991. Antioxidants and cancer, science and medicine. The babyboomers guide New Canaan connecticus keats publishing, 4: 51-61.
Chen, H.G., Yu, Y.G., Zeng, O.X. 2002. Study on extraction of flavonoids and Alkaloids from lotus leaf. Food Sci., 23: 69-71.

Gohari, A.R., Hajimehdipoor, H., Saeidnia, S., Ajani, Y., Hadjiakhoondi, A. 2011. Winter, 10-37.

Iris, F.F., Benzie and J.J. Strain. 1996. Anal. Biochem., 239: 70-76.

Mccall, M.R., Frei, B. 1999. Can antioxidant vitamins materially reduce oxidative damage in humans; Free Radical Biol. Med., 26: 1034-1053.

Patel Rajesh, M., Patel Natvar, J. 2011. J. Adv. Pharm. Education \& Res., 1: 5268.

Selvakumar, K., Madhan, R., Srinivasan, G. and Baskar, V., Rabeta, M.S. and Nur Faraniza, R. Antioxidant Assays in Pharmacological Research. IFRJ, 20(4):1691-1696.

Steinmetz, K.A., Potter, J.D. 1996. Vegetables, fruit, and cancer prevention: a review. J. Am. Diet Assoc., 96: 1027-1039.

Xianquan, S., Shi, J., Kakuda, Y., Yueming, J. 2005. Stability of lycopene during food processing and storage. J. Med. Food, 8(4): 413-22.

\section{How to cite this article:}

Suresh Babu, B., M. Lakshmi Narasu, B. Venkanna, Kodaparthi Ashwitha, CH. Kalyani and Narmada, CH. 2016. Evaluation of Antimicrobial and Antioxidative Activities of the Aerial Plant Extracts of Elytraria acaulis. Int.J.Curr.Microbiol.App.Sci. 5(8): 20-29. doi: http://dx.doi.org/10.20546/ijcmas.2016.508.003 